\title{
A review on high hydrostatic pressure for bivalve mollusk processing: relevant aspects concerning safety and quality
}

\author{
Rosiane Costa BONFIM ${ }^{1 *}$, Fabiano Alves de OLIVEIRA², Ronoel Luiz de Oliveira GODOY³, \\ Amauri ROSENTHAL ${ }^{3}$
}

\begin{abstract}
Mollusks are considered a nutritious source of food and their consumption has increased worldwide. However, their consumption, mainly of bivalves, has been considered responsible for numerous cases of foodborne diseases. This is related to their food intake, as they are filter-feeders and, consequently, bioaccumulate toxic compounds. High hydrostatic pressure (HHP) is recognized as an efficient technology to control pathogenic and deteriorating microorganisms, with low damage to the sensorial and nutritional properties of foodstuffs. This review addresses the use of HHP on bivalve mollusks, based on recent relevant studies in this field.

Keywords: shellfish; bivalves; quality; isostatic.

Practical Application: Information generated from this study provide insights into HHP application and effects on bivalve mollusks, with information on process conditions, its effects on muscle proteins and microorganisms and its impact on extending product shelf-life. These data are extremely important for the development of further industrial applications of this novel, nonthermal, fresh seafood processing technology.
\end{abstract}

\section{Introduction}

Mollusks, particularly bivalves, are often associated with food safety issues, due to recurrent episodes of gastrointestinal infections and food poisoning (Murchie et al., 2005). This is due to the physiological characteristics related to their nutrition, as they are filter-feeding animals with the capacity to bioaccumulate toxic chemicals and waterborne pathogens, including human intestinal viruses, certain sewage and wastewater bacteria, and bacteria naturally present in estuarine waters. Furthermore, toxins derived from plankton and dinoflagellates present in marine environments may also bioaccumulate in mollusks, leading to serious neurological consequences for seafood consumers (Kingsley, 2014).

Most mollusks are consumed whole, including their gastrointestinal tract, either raw or only lightly cooked (Lees, 2000), since more severe heat treatments cause detrimental effects to the taste and appearance of these marine animals, causing consumer rejection (Murchie et al., 2005).

The use of high hydrostatic pressure (HHP) on bivalve mollusks is currently under study more and of interest, due to its minimal effects on the sensorial characteristics and nutritional qualities of these organisms. This technology is used for open shucking of oysters and other mollusks, and has proven efficient in reducing microorganism loads, including of certain pathogens, such as Vibrio parahaemolyticus.

In contrast to traditional heat treatments, high pressure processing is able to reduce microbial loads without altering product physicochemical properties, since pressure is transmitted uniformly and instantaneously (isostatic process) and temperature variations in the process are low, of about $3{ }^{\circ} \mathrm{C}$ per $100 \mathrm{MPa}$ (adiabatic), depending on the food composition. These characteristics prevent food deforming or heating and any relevant organoleptic property alterations (Rendueles et al., 2011).

HHP is able to inactivate microorganisms and enzymes due to protein modifications and/or denaturation, while valuable lower molecular weight components, such as vitamins and volatile compounds, responsible for food nutritional and organoleptic quality, remain unchanged (Heinz \& Buckow, 2010). Thus, the process makes it possible to extend the shelf life of food products with minimal effect on their nutritional properties and freshness (Truong et al., 2014).

This article presents a review of the HHP process applied to bivalve mollusks, pointing out effects on microbial load, shelf life, physical structure, chemical components and the advantages of this preservation industrial process.

\section{High Hydrostatic Pressure (HHP)}

HHP technology has been widely applied in the production of meat products, dairy products, aquatic products and vegetable and fruit products, as well as various beverage products. The global market for HPP foods reached approximately $\$ 9.8$ billion in 2015 and is expected to culminate in a market value of $\$ 54.77$ billion in 2025 (Huang et al., 2017). 
HHP processing applied to food consists in subjecting the hermetically packaged food to pressures ranging from 100 to $700 \mathrm{MPa}$, for a certain time, according to the purpose and/or equipment capacity (Cheftel, 1995; Farkas \& Hoover, 2000). Food packed in flexible packages is placed in a compression chamber to undergo the pressurization process. The chamber, which is hermetically sealed, is then filled with the pressure transmitting fluid (usually water), thus expelling all the air inside the chamber. A predefined pressure is then initiated and maintained for the set time and, at the end of this cycle, the chamber is depressurized (Farkas \& Hoover, 2000; Hoover et al., 1989). As the packed food is pressurized inside the pressure chamber, this processing presents little risk of cross-recontamination and even contamination in case of operational failures (Pereira \& Vicente, 2010).

HHP is based on the Pascal (or isostatic) and Le Chatelier principles. The former states that pressure is transmitted uniformly and almost instantaneously throughout the food, regardless of its mass, size or composition (with a certain minimum moisture content required for pressure transmission), while the latter states that any phenomenon (phase transition, molecular conformation change or chemical reaction) accompanied by a reduction in volume is favored by increased pressure (and vice versa) (Barbosa-Cánovas \& Rodríguez, 2002; Cheftel, 1995).

The adiabatic condition of the process causes only a slight temperature variation with increasing pressure, regardless of the size and shape of the food, (the temperature increases approximately $3{ }^{\circ} \mathrm{C}$ per $100 \mathrm{MPa}$, depending on the food constitution), which prevents the food from being effectively deformed or heated (Chawla et al., 2011; Smelt, 1998). The pressurizing process is, therefore, independent of the volume and shape of the sample, unlike a thermal process.

However, although the food exhibits reduced compressibility, it shows a certain reduction in volume. According to Farkas \& Hoover (2000), this reduction may reach up to $15 \%$ during the process, but reverts during depressurization, and is due to changes promoted, mainly, in proteins and water molecules (Cheftel \& Culioli, 1997).

\section{HHP effect on proteins}

$\mathrm{HHP}$ processing is capable of altering the functional properties of food constituents. Protein conformation effects may lead to disruption, aggregation or gelation, depending on the protein system, applied pressure, temperature and treatment duration (Messens et al., 1997).

Under pressure, protein molecules behave according to "Le Chatelier" the law, where they suffer volume reduction due to the presence of internal spaces and the better packaging of water molecules (Cheftel \& Culioli, 1997; Truong et al., 2014). These changes may promote the reduction of up to $1.0 \%$ of the protein volume, through changes in quaternary, tertiary and secondary structures (Silva et al., 2001).

Ionic bonds and hydrophobic interactions, responsible for maintaining protein tertiary and quaternary structures, are disrupted and more easily broken at pressure levels of around 150 and $200 \mathrm{MPa}$, while the secondary structure requires higher pressures, between 300 and 700MPa (Considine et al., 2008; Heremans \& Smeller, 1998; Lullien-Pellerin \& Balny, 2002; Oliveira et al., 2017). However, the primary structure of a protein, in other words, its native structure, is not influenced by HHP, since covalent bonds display reduced compressibility (Cheftel \& Culioli, 1997).

As a consequence, complex organization structures that contain proteins, such as membranes, are altered due to the breakdown of hydrophobic and electrostatic interactions, as well as the disruption of some hydrogen bonds (Considine et al., 2008; Farkas \& Hoover, 2000). Changes in protein structure can be reflect on numerous parameters such as texture, water content and color. Table 1 provides a compilation of the main effects caused by the HHP protein structure modifications in bivalve molluscs.

In bivalve mollusks, the main function of HHP application is shucking. Thus, this process can cause the disruption of non-covalent interactions in tertiary protein structures, leading to denaturation of muscle proteins and connective tissues and, ultimately, causing the release of the adductor muscle (Rong et al., 2018; Hsu et al., 2010; Cruz-Romero et al., 2004).

The effect of HHP on shucking has always been dominated by treatment pressure and time (He et al., 2002). However several shellfish species (including bay scallops, oysters, mussels and clams) display different sensitivities to pressure or time. For example, Yi et al. (2013) observed that bay scallops were fully released at $350 \mathrm{MPa} / 0 \mathrm{~min}$ (i.e. immediate decompression), while only $18 \%$ were released at $300 \mathrm{MPa} / 0 \mathrm{~min}$, and that they were more affected by critical pressure thresholds than treatment time.

Texture is a quality parameter affected by HHP, although the measurement of texture parameters in seafood in general is controversial. Few studies concerning bivalve mollusks, in particular, are available, with no consensus. For example, some authors report increased shear strength and hardness of the adductor muscle in these animals and suggest that this may to be due to aggregation and water loss induced by denaturation in the myofibrillar fraction (Hsu et al., 2010; Yi et al., 2013; Cruz-Romero et al., 2008b, c; Lopez-Caballero et al., 2000). However, others authors report contradictory data, where sample hardness decreased after pressure application (Pérez-Won et al., 2005).

Mootian et al. (2013) observed an increase in the hardness of pressurized clams at $276 \mathrm{MPa}$ and $552 \mathrm{MPa}$ and observed that $552 \mathrm{MPa} / 3 \mathrm{~min}$ disrupted the ultra-structure of the adductor muscle and mantle from continuous tightly packed muscle fibers, to open, broken, or twisted fibers, by Scanning electron images (SEM). However, these data do not agree with the report by Pérez-Won et al. (2005), who reported that the alveolar structure of the scallop adductor muscle was destroyed after exposure to $400 \mathrm{MPa}$ for $10 \mathrm{~min}$, with reduction in the size of interfiber spaces, resulting in a more compact structure. The loss of the honeycomb structure was accompanied by a decrease in shear values, indicating firmness reduction. This data variability is due to the great diversity of species included when using the term shellfish, even between species of the same bivalve mollusk 
Bonfim et al.

Table 1. Main effects caused by protein structure modifications when applying HHP.

\begin{tabular}{|c|c|c|c|c|}
\hline Reference & Product & Treatment/Conditions & $\begin{array}{l}\text { Application/ } \\
\text { Objective }\end{array}$ & Main Conclusions \\
\hline \multirow[t]{3}{*}{ Hsu et al. (2010) } & \multirow{3}{*}{$\begin{array}{c}\text { Oyster } \\
\text { (Crassostrea gigas) }\end{array}$} & \multirow{3}{*}{$\begin{array}{l}150 \text { to } 300 \mathrm{MPa} \text { for } 0,1 \text { and } 2 \mathrm{~min}+ \\
\text { fry cooking at } 160^{\circ} \mathrm{C} \text { for } 90 \mathrm{sec}\end{array}$} & Shucking & $\begin{array}{c}\text { Shucking } \\
250 \mathrm{MPa} / 1 \mathrm{~min}-92 \%, 250 \mathrm{MPa} / 2 \mathrm{~min} \text { and } \\
300 \mathrm{MPa} / 0 \mathrm{~min}-100 \% \text { shucking }\end{array}$ \\
\hline & & & Colour & $\mathrm{L}^{* \uparrow ; \mathrm{a}^{*} \downarrow ; \mathrm{b}^{* \uparrow} ; \Delta \mathrm{E} \uparrow}$ \\
\hline & & & Texture & $300 \mathrm{MPa} / 0 \mathrm{~min}$ increased cutting force \\
\hline \multirow{3}{*}{ Yi et al. (2013) } & \multirow{3}{*}{$\begin{array}{c}\text { Scallop } \\
\text { (Aequipecten irradians) }\end{array}$} & \multirow{3}{*}{150 to $400 \mathrm{MPa}$ for 0,2 and $3 \mathrm{~min}}$. & Shucking & $\begin{array}{l}200 \mathrm{MPa} / 3 \mathrm{~min}, 300 \mathrm{MPa} / 3 \mathrm{~min}, 350 \mathrm{MPa} / 2 \mathrm{~min} \\
\text { and } 400 \mathrm{MPa} 0 \mathrm{~min}-100 \% \text { shucking }\end{array}$ \\
\hline & & & Colour & 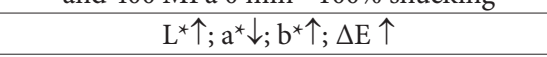 \\
\hline & & & Texture & Increased hardness by $300 \mathrm{MPa} / 0 \mathrm{~min}$ \\
\hline Rong et al. (2018) & $\begin{array}{l}\text { Oyster } \\
\text { (C. gigas })\end{array}$ & $\begin{array}{l}275,300,350 \mathrm{MPa} / 1 \mathrm{~min} \\
100,200,250,275,300 \mathrm{MPa} / 3 \mathrm{~min} \\
275 \text { and } 300 \mathrm{MPa} / 2 \mathrm{~min}\end{array}$ & Shucking & $\begin{array}{c}275 \mathrm{MPa} \text { for } 3 \mathrm{~min} \text { or } 300 \mathrm{MPa} \text { for } 2 \mathrm{~min}- \\
100 \% \text { shucking }\end{array}$ \\
\hline $\begin{array}{l}\text { Briones- } \\
\text { Labarca et al. } \\
\quad(2012)\end{array}$ & $\begin{array}{l}\text { Red abalone (Haliotis } \\
\text { rufescens) }\end{array}$ & $\begin{array}{c}500 \mathrm{MPa} / 8 \mathrm{~min}, 550 \mathrm{MPa} / 3 \mathrm{~min}, \\
550 \mathrm{MPa} / 5 \mathrm{~min} \text {, Storage at } 4{ }^{\circ} \mathrm{C} \text { for } \\
60 \text { days }\end{array}$ & Texture & $\begin{array}{l}\text { More compact structure due to protein } \\
\text { gelling. }\end{array}$ \\
\hline $\begin{array}{l}\text { Pérez-Won et al. } \\
\qquad(2005)\end{array}$ & $\begin{array}{c}\text { Scallops } \\
\text { (A. irradians) }\end{array}$ & $\begin{array}{l}\text { 400MPa+ one } 10 \text { min pulse; } \\
\text { 400MPa+two } 5 \text { min pulses; } \\
\text { 200MPa+ one } 10 \text { min pulse; } \\
\text { 200MPa+two } 5 \text { min pulses; }\end{array}$ & $\begin{array}{l}\text { Microstructure/ } \\
\text { Texture }\end{array}$ & $\begin{array}{l}\text { Hardness reduction at } 400 \mathrm{MPa}+\text { one } 10 \mathrm{~min} \\
\text { pulse and } 200 \mathrm{MPa}+\text { one } 10 \text { min pulse. } \\
\text { Compression of the muscle fibers with } \\
\text { rearrangement of the perimysium and } \\
\text { reduction of the endomysium. }\end{array}$ \\
\hline
\end{tabular}

Lopez-

Caballero et al. (2000)
Oysters

(Ostraea edulis)
$400 \mathrm{MPa}$ at $7^{\circ} \mathrm{C}$ for $10 \mathrm{~min}$ or $400 \mathrm{MPa}$ at $7^{\circ} \mathrm{C}$ for $5 \mathrm{~min}$ in two consecutive steps.
Texture

$400 \mathrm{MPa}$ por 5 and $10 \mathrm{~min}$ - Increase in the shear strength in storage

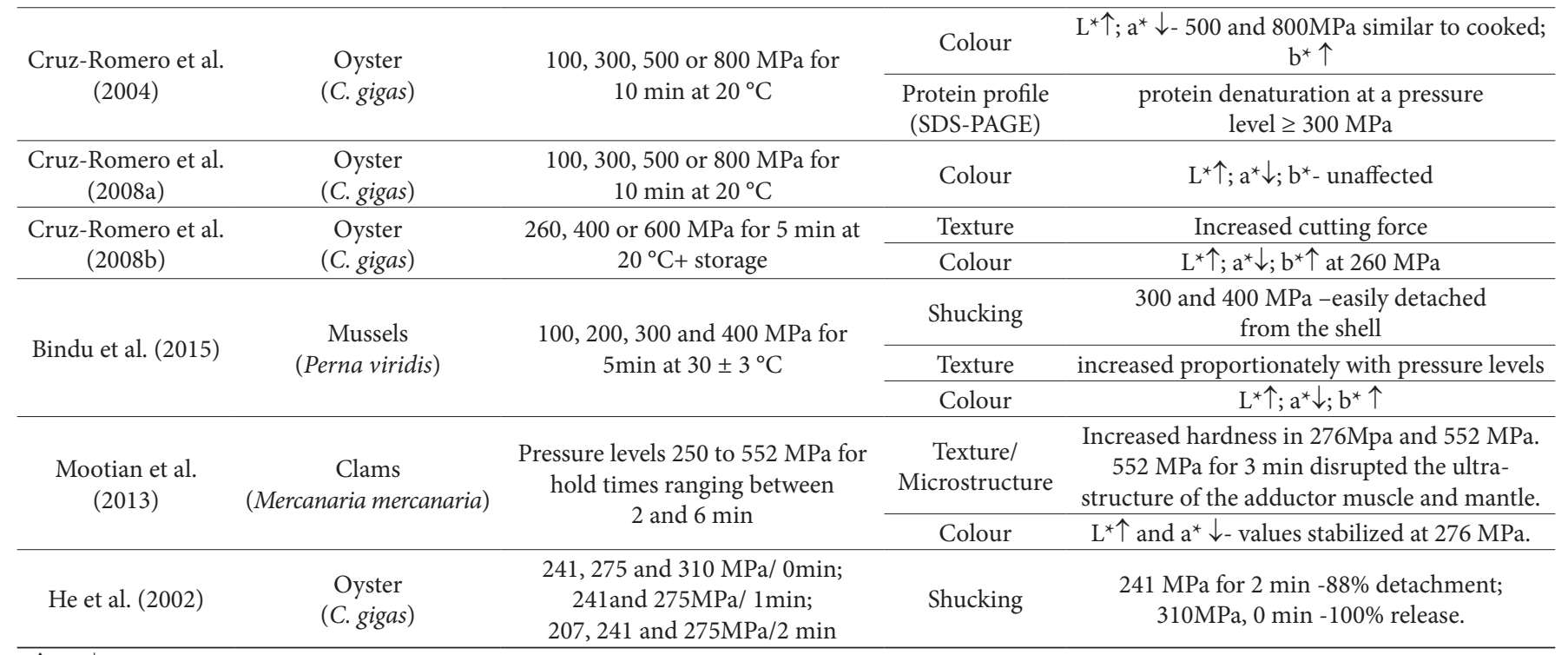

* $\uparrow$ and $\downarrow$ : increase or decrease in color index as a function of HP processing parameters.

genus, and also due to the variety of methodologies for gauging mollusk texture.

Another very important quality parameter concerning HPP-processed bivalve mollusks is color. According to Cruz-Romero et al. (2004, 2007, 2008a, b, c) regarding oysters and Briones-Labarca et al. (2012) for abalones, the $L^{*}$ value increases with increasing pressure, indicating that HHP treatment could lead a to the brighter and less transparent adductor tissue. After high pressure treatment, seafood showed an opaque appearance similar to that obtained by very light cooking (Murchie et al., 2005). Muscle paleness after HHP treatment resulted in brightness increases, and it was not only accounted for loss of active pigment, but also for protein coagulation, altering sample surface properties, reflecting reflected light and creating the whitish color (Kruk et al., 2011).

Although some differences are noted between different studies, most have reported decreased $\mathrm{a}^{*}$ (loss of red) and increased $\mathrm{b}^{*}$ (yellow), which varies according to species and pressurization 
parameters (Table 1). The parameters that make up color in scallops, for example, can display great variability, as migration of carotenoids from the gonads to the adductor muscle occurs due to not yet fully elucidated genetic mechanisms ( $\mathrm{Li}$ et al., 2010; Du et al., 2017). According to Rodriguez-Amaya (1993), lipid oxidation is another cause of colour loss in fish products, due to the degradation of highly unsaturated carotenoids such as astaxanthin, one of the major pigments in shellfish and fish products.

\section{HHP effect on microorganisms}

High pressures cause morphological, biochemical and genetic changes, especially in membranes, leading to changes in microorganism functioning and reproduction (Cheftel \& Culioli, 1997), including gaseous vacuole compression, cell stretching, cell wall membrane separation, cell wall contraction with pore formation, cytoskeletal modifications and nucleus and intracellular organelles changes (Campos et al., 2003). In addition, HHP increases cell permeability, inhibits energetic reactions and denatures enzymes essential for microorganism growth and reproduction (Calderón-Miranda et al., 1998).

Due to its special characteristics, the cell membrane is the main target of HHP treatment (Smelt, 1998), mainly resulting in permeability and functionality modifications (Pagán \& Mackey, 2000). One hypothesis for microbial inactivation by HHP is linked to the decrease of sodium and potassium-dependent ATPase activity, located in the phospholipid layer of the cell membrane and involved in active membrane transport. In this way, ATPase becomes unable to maintain proton transport through the membrane causing internal $\mathrm{pH}$ decreases and cell death (Cheftel \& Culioli, 1997).

However, it seems that no single damage to a cellular structure or function is responsible for microorganism inactivation; cell death is due to a multiplicity of accumulated damages in different parts of the cell (Hoover et al., 1989). Thus, when accumulated damages exceed the ability of a cell to repair itself, cell death occurs (Rendueles et al., 2011).

Recently Rong et al. (2018) published a study on the use of high throughput sequencing (HTS) to investigate control microbiota and oysters treated with HPP during refrigerated storage. Fresh oysters (hand-shucked) were compared to a $300 \mathrm{MPa}$ treatment for $2 \mathrm{~min}$, due to its presented shucking efficiency. Shelf life was evaluated and fresh oyster samples became sensorially unacceptably on the eighth day of storage and microbiologically unfit for consumption on the sixth day of storage. Oysters treated with HPP, on the other hand, were valid for 12 days, as HPP promoted a reduction of 1.27 logs cycles $(\mathrm{P}<0.01)$. A principal component analysis (PCA) concerning odor analysis by electronic nose demonstrated discrepant positions for fresh, damaged and pressurized samples, confirming the hypothesis that HPP altered the oyster deterioration process during storage, influencing their microbiota. The dominant bacteria present in fresh oysters were Vibrio, Shewanella and Pseudoalteromonas, with Pseudoalteromonas and Shewanella dominant in spoiled oysters. The HPP treatment altered oyster deterioration microbiota dramatically, with Psychrobacter dominant in HPP treated spoiled oysters. Table 2 displays the main research on HHP applications in bivalve mollusks.

Table 2. Compiled on the effect of HHP on the microbiota of bivalve molluscs.

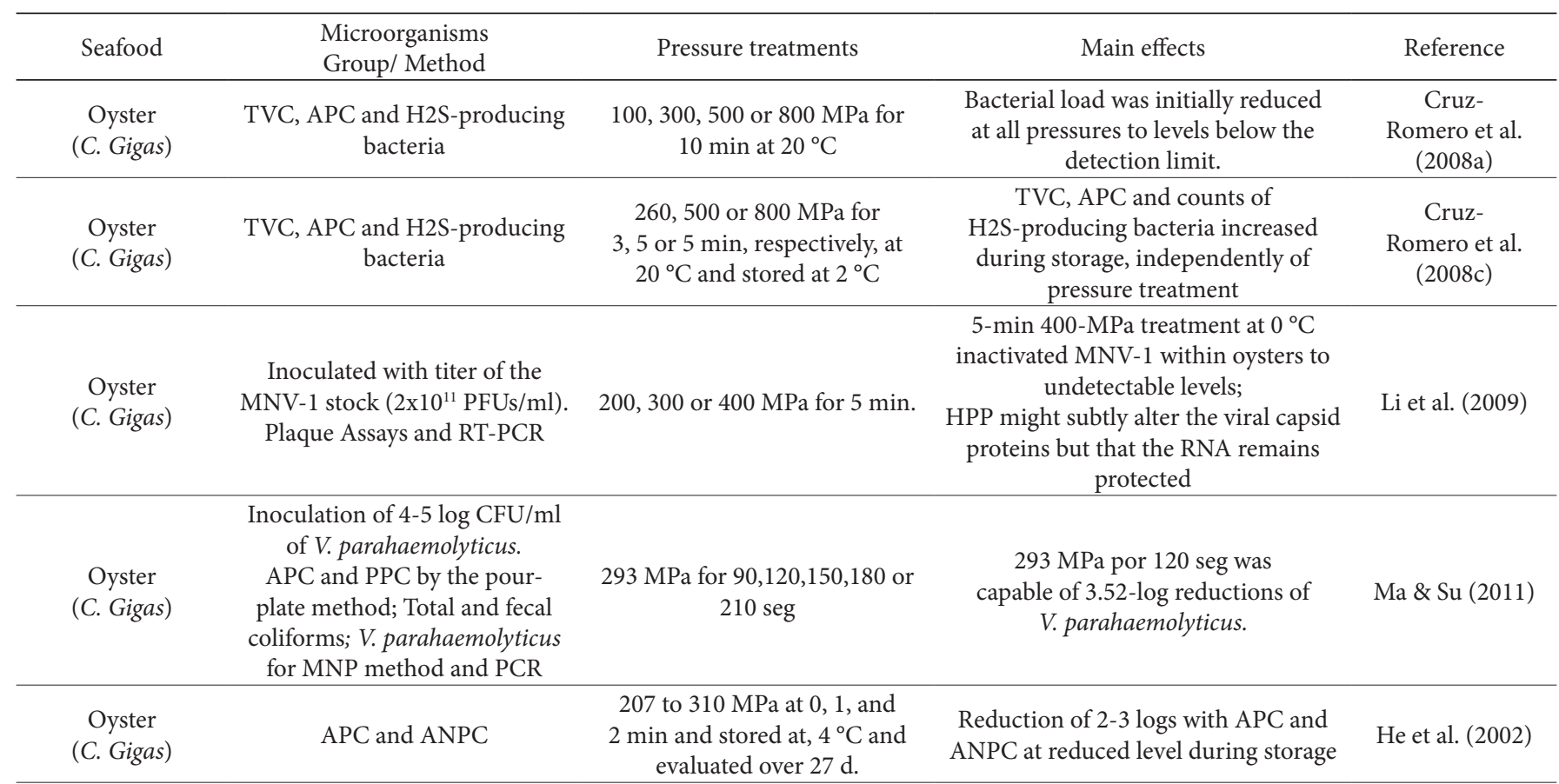

$\mathrm{APC}=$ Aerobic plate counts $\mathrm{PPC}=$ Psychrotrophic plate counts; $\mathrm{ANPC}=$ Anaerobic plate counts $\mathrm{CFU}=$ colony-forming units; $\mathrm{MPN}=\mathrm{most}$ probable number; $\mathrm{PFU}=$ plaque-forming units; TVC = Total viable counts; PCR = polymerase chain reaction; RT-PCR = reverse transcription- polymerase chain reaction; TABC = numbers of total aerobic bacterial counts. 
Table 2. Continued...

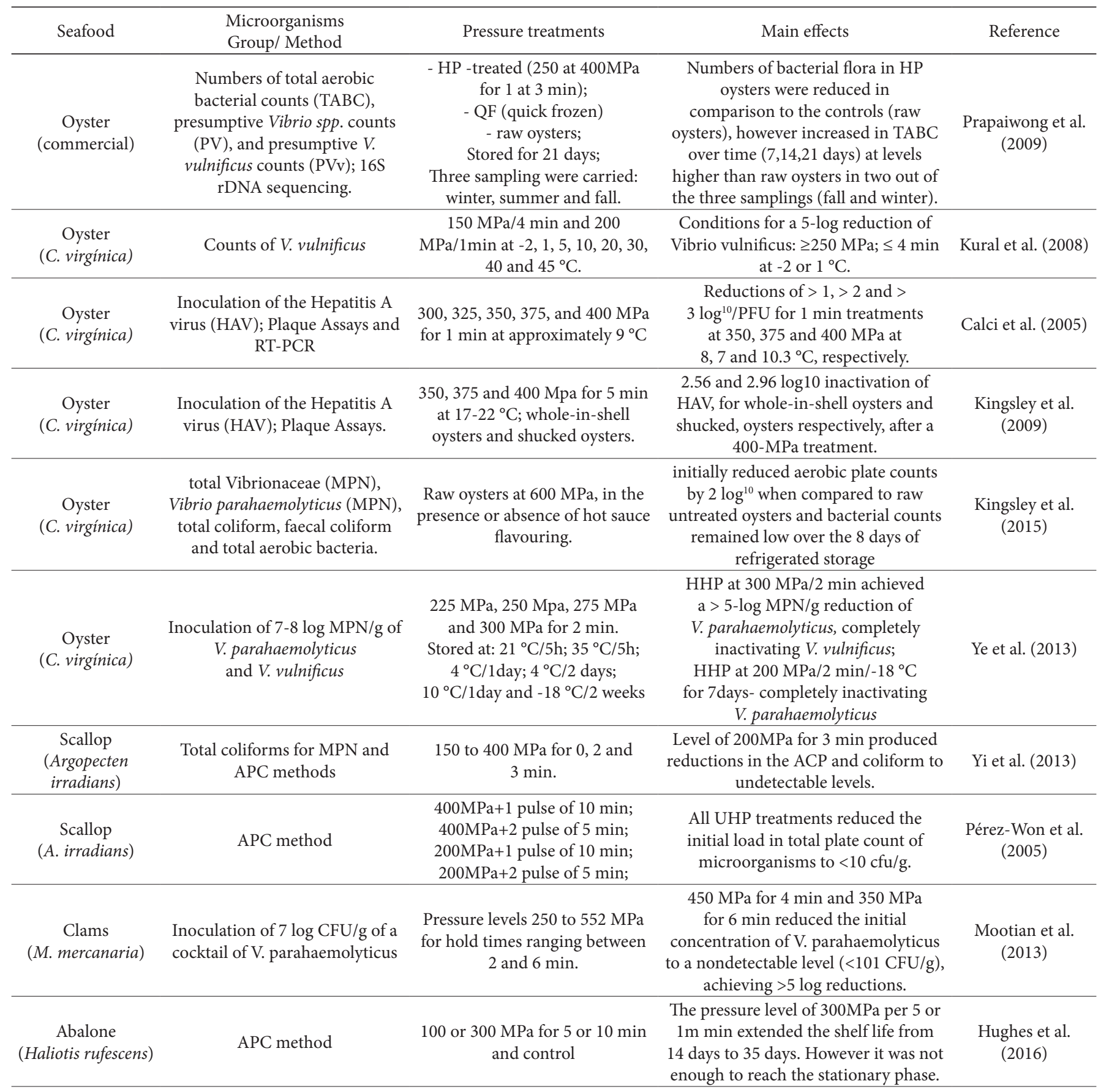

$\mathrm{APC}=$ Aerobic plate counts; $\mathrm{PPC}=$ Psychrotrophic plate counts; $\mathrm{ANPC}=$ Anaerobic plate counts; $\mathrm{CFU}=$ colony-forming units; $\mathrm{MPN}=$ most probable number; $\mathrm{PFU}=$ plaque-forming units; TVC $=$ Total viable counts; $\mathrm{PCR}=$ polymerase chain reaction; RT-PCR $=$ reverse transcription- polymerase chain reaction; $\mathrm{TABC}=$ numbers of total aerobic bacterial counts.

Viruses are of great concern in foods, as they are obligatory intracellular parasites and can only replicate inside suitable living host cells. As a result, viruses cannot multiply in the environment or in foods, so traditional factors used to control bacterial levels in food systems (e.g., acidified $\mathrm{pH}$, reduced temperature, or reduced water activity) are ineffective as barriers to viral hazards (Jaykus, 2000). In the case of viruses, experiments suggest that HHP inactivates viruses through the denaturation of their capsid proteins, which renders them unable to bind to their receptor on the surface of their host cell (Kingsley, 2014).
Investigations concerning the potential of HPP in inactivating human norovirus and hepatitis A virus, currently considered the two most significant foodborne virus threats in raw bivalve shellfish, have demonstrated that pressures $\geq 400 \mathrm{MPa}$ will inactivate these viruses in shellfish tissues (Kingsley et al., 2002, 2005, 2007, 2009; Calci et al., 2005; Terio et al., 2010; Leon et al., 2011; Ye et al., 2014).

The efficiency of HHP technology in inactivating microorganisms depends, mainly, on the magnitude of the 
applied pressure, pressurizing time, process temperature and type of microorganism, as well as cell growth phase, type of food material and the presence of microbial agents, among others (Farkas \& Hoover, 2000).

HHP processing, alone or alongside other methods, has been investigated as a way to reduce pathogenic microorganism contamination in bivalve mollusks, mainly concerning Vibrio parahaemolyticus and Vibrio vulnificus. In addition, it is used to reduce spoilage burdens and, thus, extend seafood shelf life (He et al., 2002; Hughes et al., 2016; Mootian et al., 2013; Phuvasate \& Su, 2015; Ye et al., 2012, 2013). In addition, reports of the potential use of HHP against hepatitis A virus and calicivirus are also found in the literature (Calci et al., 2005).

\section{HHP effect on nutritional and sensory aspects}

Food conservation by HHP originates from HPP ability to conserve original color, flavor, aroma, quality and nutritional content attributes. Pressurization is able to alter the structure of high molecular weight molecules, such as proteins and carbohydrates, while smaller molecules, such as volatile compounds, pigments, vitamins and other compounds related to sensory, nutritional and health characteristics, are less affected. Thus, this method is able to provide products displaying sensorial characteristics very close to those of the fresh food without the addition of preservatives (additives), while also displaying a favorable effect on texture characteristics and other desirable attributes, such as digestibility (Chawla et al., 2011; Ginson et al., 2015).

Some authors have reported that HHP may increase the total amount of carotenoids available in vegetable matrices (Patras et al., 2009a, b; Plaza et al., 2006; Sánchez-Moreno et al., 2005), and theorized that pressure modifies the permeability of the cell membrane and denatures carotenoid-bound proteins, at the same time making proteins more available (Barba et al., 2015). However, no studies along these lines are available for mollusks and fishes.

Kingsley et al. (2015) evaluated consumer acceptance of HHP (whole shell) treated oysters at 300,400 and $500 \mathrm{MPa}$ at $22{ }^{\circ} \mathrm{C}$ and 400,500 and $600 \mathrm{MPa}$ at $6{ }^{\circ} \mathrm{C}$. All HHP-treated samples received the highest scores applying a hedonic scale for attributes such as appearance and texture in relation to control samples, indicating the possibility of the use of this technology for oyster processing.

However, marine foods are characterized by high levels of polyunsaturated fatty acids (PUFAs), such as eicosapentaenoic acid (EPA) and docosahexaenoic acid (DHA), which are highly susceptible to oxidation and oxidative lipid degradation during storage, directly affecting the quality of these products, impacting taste, color, texture and nutritional value. Lipid systems are the biological components most sensitive to pressure, mainly due to the predominance of hydrophobic bonds, which are very susceptible to the process (Medina-Meza et al., 2014).

A pressure level of $300 \mathrm{MPa}$ leads to a small effect on lipid oxidation, which increases linearly at higher pressures. In the case of shellfish and marine animals in general, the presence of PUFAs promotes radical production, leading to accelerated oxidation in subsequent storage periods. However, HHP can be combined with other methods that perform post-pressurizing antioxidant functions (Medina-Meza et al., 2014).

\section{Advantages, challenges and perspectives}

HHP technology displays many advantages over conventional methods, incuding uniform pressure distribution throughout the food with minimal increases in temperature, possibility of safely extending product shelf life with only minimal nutritional and sensorial losses, and only requiring a small amount of energy for the compression of a solid or a liquid, compared to heating the product at $100{ }^{\circ} \mathrm{C}$. In addition, the technology is applicable to packaged foods, thus preventing unnecessary and obsolete recontamination or the need for aseptic packaging processes (Pereira \& Vicente, 2010).

HHP consumes relatively low energy and requires low amounts of potable water, thus reducing its carbon footprint and decreasing effluent production, since the pressure transmission liquid (usually water) can be recycled. Consequently HHP can be considered an environmentally sustainable process (Truong et al., 2014).

Bermúdez-Aguirre \& Barbosa-Cánovas (2011) pointed out that the number of HHP devices worldwide has developed at an annual exponential rate in several countries over the last 20 years, and that, currently, the use of HHP by food industries and the sale of pressurized products is a reality, ranging from fruits and vegetables to seafood and eggs, with wide consumer acceptance. In addition, Huang and colleagues (Huang et al., 2017) recently published a report on HHP growth and relevance in the food sector, and highlighted that this technology is the most commonly applied non-thermal processing technique in the world.

The Food and Drug Administration (FDA) and US Department of Agriculture (USDA) have approved the technology as a food preservation method, and the US National Advisory Committee on Microbiological Criteria for Foods regards $\mathrm{HHP}$ as a Non-thermal pasteurization process that can replace conventional pasteurization (Wang et al., 2013).

However, the method still presents obstacles to large-scale applications in the food industry, mainly in relation to the high initial capital to be invested. Besides the cost of the equipment, the use of HHP for shellfish and marine animals can be hampered due to seasonality. Although fish and shellfish can be consumed throughout the year, there may be peaks in production and consumption during certain periods. Thus, in order to meet product demand during harvesting periods, the company may be required to install more than one HHP unit (Sousa \& Gonçalves, 2013), besides utilizing alternative products considering seasonality.

Although HHP is able to preserve the nutritional and sensory characteristics of foods, the full effects of treatment require individual study, due to the complexity of each food composition and the possibilities for changes and intrinsic reactions that may occur during pressurization. Therefore, several studies have been carried out to investigate microorganism and enzyme inactivation 
kinetics, biopolymer structures (proteins, polysaccharides), as well as the effect on specific constituents of food products (juices, dairy products, meats, fish, fruits and vegetables). This aspect is related to the fact that HHP is associated with and a promising tool not only for food preservation, but also because of its potential to promote positive effects on technological properties and to preserve the functional and nutritional characteristics of the food constituents. However, these effects, properties and characteristics should be studied both in the integrated system and concerning individual components.

\section{Conclusions}

The international fishing industry currently applies HHP in commercial oyster processing. However, further studies are required concerning its effects on biochemical and microflora characteristics in order to overcome the health risks associated with bivalve mollusk consumption. HHP displays many advantages, as it is a non-thermal technology compared to conventional treatments in relation to the preservation of food nutritional composition and sensory quality. Moreover, it is a clean technology, since it presents a significantly lower carbon footprint than thermal methods.

The limiting factor to its implementation remains the high capital cost of the technology. However considering its benefits, the resulting potential value aggregation and prospects of technological development, it is expected that implementation costs will become more accessible, expanding HHP use for the processing of bivalve mollusks and other shellfish in general.

\section{References}

Barba, F. J., Terefe, N. S., Buckow, R., Knorr, D., \& Orlien, V. (2015). New opportunities and perspectives of high pressure treatment to improve health and safety attributes of foods. A review. Food Research International, 77, 725-742. http://dx.doi.org/10.1016/j. foodres.2015.05.015.

Barbosa-Cánovas, G. V., \& Rodríguez, J. J. (2002). Update on nonthermal food processing technologies: pulsed electric field, high hydrostatic pressure, irradiation and ultrasound. Food Australia, 54(11), 513-520.

Bermúdez-Aguirre, D., \& Barbosa-Cánovas, G. V. (2011). An update on high hydrostatic pressure, from the laboratory to industrial applications. Food Engineering Reviews, 3(1), 44-61. http://dx.doi. org/10.1007/s12393-010-9030-4.

Bindu, J., Ginson, J., Kamalakanth, C. K., \& Gopal, T. K. S. (2015). High pressure treatment of green mussel Perna viridis Linnaeus, 1758: effect on shucking and quality changes in meat during chill storage. Indian Journal of Fisheries, 62(2)

Briones-Labarca, V., Perez-Won, M., Zamarca, M., Aguilera-Radic, J. M., \& Tabilo-Munizaga, G. (2012). Effects of high hydrostatic pressure on microstructure, texture, colour and biochemical changes of red abalone (Haliotis rufecens) during cold storage time. Innovative Food Science \& Emerging Technologies, 13, 42-50. http://dx.doi. org/10.1016/j.ifset.2011.09.002.

Calci, K. R., Meade, G. K., Tezloff, R. C., \& Kingsley, D. H. (2005). Highpressure inactivation of hepatitis A virus within oysters. Applied and Environmental Microbiology, 71(1), 339-343. http://dx.doi. org/10.1128/AEM.71.1.339-343.2005. PMid:15640207.
Calderón-Miranda, M., González, M., Barbosa-Cánovas, G. V., \& Swanson, B. G. (1998). Métodos no térmicos para procesamiento de alimentos: variables e inactivación microbiana. Brazilian Journal of Food Technology, 1, 3-11.

Campos, F., Dosualdo, G., \& Cristianini, M. (2003). Utilização da tecnologia de alta pressão no processamento de alimentos. Brazilian Journal of Food Technology, 6(2), 351-357.

Chawla, R., Patil, G. R., \& Singh, A. K. (2011). High hydrostatic pressure technology in dairy processing: a review. Journal of Food Science and Technology, 48(3), 260-268. http://dx.doi.org/10.1007/s13197010-0180-4. PMid:23572744.

Cheftel, J. C. (1995). Review: high-pressure, microbial inactivation and food preservation/revision: alta-presion, inactivacion microbiologica y conservacion de alimentos. Food Science \& Technology International, 1(2-3), 75-90. http://dx.doi.org/10.1177/108201329500100203.

Cheftel, J. C., \& Culioli, J. (1997). Effects of high pressure on meat: a review. Meat Science, 46(3), 211-236. http://dx.doi.org/10.1016/ S0309-1740(97)00017-X. PMid:22062123.

Considine, K. M., Kelly, A. L., Fitzgerald, G. F., Hill, C., \& Sleator, R. D. (2008). High-pressure processing-effects on microbial food safety and food quality. FEMS Microbiology Letters, 281(1), 1-9. http:// dx.doi.org/10.1111/j.1574-6968.2008.01084.x. PMid:18279335.

Cruz-Romero, M., Kelly, A., \& Kerry, J. (2007). Effects of high-pressure and heat treatments on physical and biochemical characteristics of oysters (Crassostrea gigas). Innovative Food Science \& Emerging Technologies, 8(1), 30-38. http://dx.doi.org/10.1016/j.ifset.2006.05.002.

Cruz-Romero, M. C., Kerry, J. P., \& Kelly, A. L. (2008a). Fatty acids, volatile compounds and colour changes in high-pressure-treated oysters (Crassostrea gigas). Innovative Food Science \& Emerging Technologies, 9(1), 54-61. http://dx.doi.org/10.1016/j.ifset.2007.05.003.

Cruz-Romero, M., Kerry, J. P., \& Kelly, A. L. (2008b). Changes in the microbiological and physicochemical quality of high-pressure-treated oysters (Crassostrea gigas) during chilled storage. Food Control, 19(12), 1139-1147. http://dx.doi.org/10.1016/j.foodcont.2007.12.004.

Cruz-Romero, M., Kelly, A. L., \& Kerry, J. P. (2008c). Effects of highpressure treatment on the microflora of oysters (Crassostrea gigas) during chilled storage. Innovative Food Science \& Emerging Technologies, 9(4), 441-447. http://dx.doi.org/10.1016/j.ifset.2008.04.002.

Cruz-Romero, M., Smiddy, M., Hill, C., Kerry, J., \& Kelly, A. (2004). Effects of high pressure treatment on physicochemical characteristics of fresh oysters (Crassostrea gigas). Innovative Food Science \& Emerging Technologies, 5(2), 161-169. http://dx.doi.org/10.1016/j. ifset.2004.01.002.

Du, X., Song, K., Wang, J., Cong, R., Li, L., \& Zhang, G. (2017). Draft genome and SNPs associated with carotenoid accumulation in adductor muscles of bay scallop (Argopecten irradians). Journal of Genomics, 5, 83-90. http://dx.doi.org/10.7150/jgen.19146. PMid:28775792.

Farkas, D. F., \& Hoover, D. G. (2000). High pressure processing. Journal of Food Science, 65(s8), 47-64. http://dx.doi.org/10.1111/j.1750-3841.2000. tb00618.x.

Ginson, J., Panda, S. K., Bindu, J., Kamalakanth, C. K., \& Srinivasa Gopal, T. K. (2015). Effect of high pressure treatment on microbiological quality of Indian white prawn (Fenneropenaeus indicus) during chilled storage. Food Microbiology, 46, 596-603. http://dx.doi. org/10.1016/j.fm.2014.10.008. PMid:25475333.

He, H., Adams, R., Farkas, D., \& Morrissey, M. (2002). Use of high-pressure processing for oyster shucking and shelf-life extension. Journal of Food Science, 67(2), 640-645. http://dx.doi.org/10.1111/j.1365-2621.2002. tb10652.x. 
Heinz, V., \& Buckow, R. (2010). Food preservation by high pressure. Journal für Verbraucherschutz und Lebensmittelsicherheit, 5(1), 7381. http://dx.doi.org/10.1007/s00003-009-0311-x.

Heremans, K., \& Smeller, L. (1998). Protein structure and dynamics at high pressure1. Biochimica et Biophysica Acta (BBA) -. Protein Structure and Molecular Enzymology, 1386(2), 353-370. http://dx.doi. org/10.1016/S0167-4838(98)00102-2.

Hoover, D. G., Metrick, C., Papineau, A., Farkas, D., \& Knorr, D. (1989). Biological effects of high hydrostatic pressure on food microorganisms. Food Technology, 43, 99-107.

Hsu, K. C., Hwang, J. S., Chi, H. Y., \& Lai, K. M. (2010). Effect of different high pressure treatments on shucking, biochemical, physical and sensory characteristics of oysters to elaborate a traditional Taiwanese oyster omelette. Journal of the Science of Food and Agriculture, 90(3), 530-535. PMid:20355076.

Huang, H.-W., Wu, S.-J., Lu, J.-K., Shyu, Y.-T., \& Wang, C.-Y. (2017). Current status and future trends of high-pressure processing in food industry. Food Control, 72, 1-8. http://dx.doi.org/10.1016/j. foodcont.2016.07.019.

Hughes, B. H., Perkins, L. B., Yang, T. C., \& Skonberg, D. I. (2016). Impact of post-rigor high pressure processing on the physicochemical and microbial shelf-life of cultured red abalone (Haliotis rufescens). Food Chemistry, 194, 487-494. http://dx.doi.org/10.1016/j. foodchem.2015.07.144. PMid:26471583.

Jaykus, L. (2000). Enteric viruses as 'emerging agents' of foodborne disease. Irish Journal of Agricultural and Food Research, 39(2), 245-255.

Kingsley, D. H. (2014). High pressure processing of bivalve shellfish and HPP's use as a virus intervention. Foods, 3(2), 336-350. http:// dx.doi.org/10.3390/foods3020336. PMid:28234323.

Kingsley, D. H., Calci, K., Holliman, S., Dancho, B., \& Flick, G. (2009). High pressure inactivation of HAV within oysters: comparison of shucked oysters with whole-in-shell meats. Food and Environmental Virology, 1(3-4), 137-140. http://dx.doi.org/10.1007/s12560-009-9018-5.

Kingsley, D. H., Duncan, S. E., Granata, L. A., Salinas-Jones, A., Flick, G. J. Jr., Bourne, D. M., \& Fernandez-Plotka, V. C. (2015). Highpressure processing with hot sauce flavouring enhances sensory quality for raw oysters (Crassostrea virginica). International Journal of Food Science \& Technology, 50(9), 2013-2021. http://dx.doi. org/10.1111/ijfs.12852.

Kingsley, D. H., Guan, D., \& Hoover, D. G. (2005). Pressure inactivation of hepatitis A virus in strawberry puree and sliced green onions. Journal of Food Protection, 68(8), 1748-1751. http://dx.doi.org/10.4315/0362028X-68.8.1748. PMid:21132991.

Kingsley, D. H., Holliman, D. R., Calci, K. R., Chen, H., \& Flick, G. J. (2007). Inactivation of a norovirus by high-pressure processing. Applied and Environmental Microbiology, 73(2), 581-585. http:// dx.doi.org/10.1128/AEM.02117-06. PMid:17142353.

Kingsley, D. H., Hoover, D. G., Papafragkou, E., \& Richards, G. P. (2002). Inactivation of hepatitis A virus and a calicivirus by high hydrostatic pressure. Journal of Food Protection, 65(10), 1605-1609. http://dx.doi.org/10.4315/0362-028X-65.10.1605. PMid:12380746.

Kruk, Z. A., Yun, H., Rutley, D. L., Lee, E. J., Kim, Y. J., \& Jo, C. (2011). The effect of high pressure on microbial population, meat quality and sensory characteristics of chicken breast fillet. Food Control, 22(1), 6-12. http://dx.doi.org/10.1016/j.foodcont.2010.06.003.

Kural, A. G., Shearer, A. E., Kingsley, D. H., \& Chen, H. (2008). Conditions for high pressure inactivation of Vibrio parahaemolyticus in oysters. International Journal of Food Microbiology, 127(1-2), 1-5. http:// dx.doi.org/10.1016/j.ijfoodmicro.2008.05.003. PMid:18547664.
Lees, D. (2000). Viruses and bivalve shellfish. International Journal of Food Microbiology, 59(1-2), 81-116. http://dx.doi.org/10.1016/ S0168-1605(00)00248-8. PMid:10946842.

Leon, J. S., Kingsley, D. H., Montes, J. S., Richards, G. P., Lyon, G. M., Abdulhafid, G. M., Seitz, S. R., Fernandez, M. L., Teunis, P. F., Flick, G. J., \& Moe, C. L. (2011). Randomized, double-blinded clinical trial for human norovirus inactivation in oysters by high hydrostatic pressure processing. Applied and Environmental Microbiology, 77(15), 54765482. http://dx.doi.org/10.1128/AEM.02801-10. PMid:21705552.

Li, D., Tang, Q., Wang, J., Wang, Y., Zhao, Q., \& Xue, C. (2009). Effects of high-pressure processing on murine norovirus-1 in oysters (Crassostrea gigas) in situ. Food Control, 20(11), 992-996.

Li, N., Hu, J. J., Wang, S., Cheng, J., Hu, X. L., Lu, Z. Y., Lin, Z., Zhu, W., \& Bao, Z. (2010). Isolation and identification of the main carotenoid pigment from the rare orange muscle of the Yesso scallop. Food Chemistry, 118(3), 616-619. http://dx.doi.org/10.1016/j. foodchem.2009.05.043.

Lopez-Caballero, M. E., Pérez-Mateos, M., Montero, P., \& Borderías, A. J. (2000). Oyster preservation by high-pressure treatment. Journal of Food Protection, 63(2), 196-201. http://dx.doi.org/10.4315/0362028X-63.2.196. PMid:10678424.

Lullien-Pellerin, V., \& Balny, C. (2002). High-pressure as a tool to study some proteins' properties: conformational modification, activity and oligomeric dissociation. Innovative Food Science \& Emerging Technologies, 3(3), 209-221. http://dx.doi.org/10.1016/ S1466-8564(02)00045-0.

Ma, L., \& Su, Y. C. (2011). Validation of high pressure processing for inactivating Vibrio parahaemolyticus in Pacific oysters (Crassostrea gigas). International Journal of Food Microbiology, 144(3), 469-474. http://dx.doi.org/10.1016/j.ijfoodmicro.2010.10.037. PMid:21106267.

Medina-Meza, I. G., Barnaba, C., \& Barbosa-Cánovas, G. V. (2014). Effects of high pressure processing on lipid oxidation: a review. Innovative Food Science \& Emerging Technologies, 22, 1-10. http:// dx.doi.org/10.1016/j.ifset.2013.10.012.

Messens, W., Van Camp, J., \& Huyghebaert, A. (1997). The use of high pressure to modify the functionality of food proteins. Trends in Food Science \& Technology, 8(4), 107-112. http://dx.doi.org/10.1016/ S0924-2244(97)01015-7.

Mootian, G. K., Flimlin, G. E., Karwe, M. V., \& Schaffner, D. W. (2013). Inactivation of vibrio parahaemolyticus in hard clams (Mercanaria mercanaria) by High Hydrostatic Pressure (HHP) and the effect of HHP on the physical characteristics of hard clam meat. Journal of Food Science, 78(2), E251-E257. http://dx.doi.org/10.1111/17503841.12014. PMid:23324022.

Murchie, L. W., Cruz-Romero, M., Kerry, J. P., Linton, M., Patterson, M. F., Smiddy, M., \& Kelly, A. L. (2005). High pressure processing of shellfish: a review of microbiological and other quality aspects. Innovative Food Science \& Emerging Technologies, 6(3), 257-270. http://dx.doi.org/10.1016/j.ifset.2005.04.001.

Oliveira, F. A. D., Cabral, O. No., Santos, L. M. R. D., Ferreira, E. H. R., \& Rosenthal, A. (2017). Effect of high pressure on fish meat quality - a review. Trends in Food Science \& Technology, 66, 1-19. http://dx.doi.org/10.1016/j.tifs.2017.04.014.

Pagán, R., \& Mackey, B. (2000). Relationship between membrane damage and cell death in pressure-treated Escherichia coli cells: differences between exponential-and stationary-phase cells and variation among strains. Applied and Environmental Microbiology, 66(7), 2829-2834. http://dx.doi.org/10.1128/AEM.66.7.2829-2834.2000. PMid:10877775.

Patras, A., Brunton, N. P., Da Pieve, S., \& Butler, F. (2009a). Impact of high pressure processing on total antioxidant activity, phenolic, ascorbic acid, anthocyanin content and colour of strawberry and 
blackberry purées. Innovative Food Science \& Emerging Technologies, 10(3), 308-313. http://dx.doi.org/10.1016/j.ifset.2008.12.004.

Patras, A., Brunton, N., Da Pieve, S., Butler, F., \& Downey, G. (2009b). Effect of thermal and high pressure processing on antioxidant activity and instrumental colour of tomato and carrot purées. Innovative Food Science \& Emerging Technologies, 10(1), 16-22. http://dx.doi. org/10.1016/j.ifset.2008.09.008.

Pereira, R., \& Vicente, A. (2010). Environmental impact of novel thermal and non-thermal technologies in food processing. Food Research International, 43(7), 1936-1943. http://dx.doi.org/10.1016/j. foodres.2009.09.013.

Pérez-Won, M., Tabilo-Munizaga, G., \& Barbosa-Cánovas, G. V. (2005). Effects of ultra high pressure on bay scallop (Aequipecten irradians) adductor muscles. Food Science \& Technology International, 11(6), 477-484. http://dx.doi.org/10.1177/1082013205060761.

Phuvasate, S., \& Su, Y. C. (2015). Efficacy of low-temperature high hydrostatic pressure processing in inactivating Vibrio parahaemolyticus in culture suspension and oyster homogenate. International Journal of Food Microbiology, 196, 11-15. http://dx.doi.org/10.1016/j. ijfoodmicro.2014.11.018. PMid:25498471.

Plaza, L., Sánchez-Moreno, C., De Ancos, B., \& Cano, M. P. (2006). Carotenoid content and antioxidant capacity of Mediterranean vegetable soup (gazpacho) treated by high-pressure/temperature during refrigerated storage. European Food Research and Technology, 223(2), 210-215. http://dx.doi.org/10.1007/s00217-005-0174-z.

Prapaiwong, N., Wallace, R. K., \& Arias, C. R. (2009). Bacterial loads and microbial composition in high pressure treated oysters during storage. International Journal of Food Microbiology, 131(2-3), 145-150. http://dx.doi.org/10.1016/j.ijfoodmicro.2009.02.014. PMid:19303653.

Rendueles, E., Omer, M. K., Alvseike, O., Alonso-Calleja, C., Capita, R., \& Prieto, M. (2011). Microbiological food safety assessment of high hydrostatic pressure processing: a review. Lebensmittel-Wissenschaft + Technologie, 44(5), 1251-1260. http://dx.doi.org/10.1016/j. lwt.2010.11.001.

Rodriguez-Amaya, D. B. (1993). Nature and distribution of carotenoids in foods. Developments in Food Science, 547-589.

Rong, C., Ling, Z., Huihui, S., \& Qi, L. (2018). Characterization of microbial community in high-pressure treated oysters by highthroughput sequencing technology. Innovative Food Science \& Emerging Technologies, 45, 241-248. http://dx.doi.org/10.1016/j. ifset.2017.11.001.

Sánchez-Moreno, C., Plaza, L., Elez-Martínez, P., De Ancos, B., MartínBelloso, O., \& Cano, M. P. (2005). Impact of high pressure and pulsed electric fields on bioactive compounds and antioxidant activity of orange juice in comparison with traditional thermal processing.
Journal of Agricultural and Food Chemistry, 53(11), 4403-4409. http://dx.doi.org/10.1021/jf048839b. PMid:15913302.

Silva, J. L., Foguel, D., \& Royer, C. A. (2001). Pressure provides new insights into protein folding, dynamics and structure. Trends in Biochemical Sciences, 26(10), 612-618. http://dx.doi.org/10.1016/ S0968-0004(01)01949-1. PMid:11590014.

Smelt, J. P. P. M. (1998). Recent advances in the microbiology of high pressure processing. Trends in Food Science \& Technology, 9(4), 152-158. http://dx.doi.org/10.1016/S0924-2244(98)00030-2.

Sousa, Ê. S., \& Gonçalves, A. A. (2013). Tecnologia de alta pressão aplicada ao pescado (Vol. 1, pp. 66). Laguna: Aquaculture Brasil. Retrieved from https://www.researchgate.net/publication/308120267_ Tecnologia_de_alta_pressao_aplicada_ao_pescado

Terio, V., Tantillo, G., Martella, V., Pinto, P. D., Buonavoglia, C., \& Kingsley, D. H. (2010). High pressure inactivation of HAV within mussels. Food and Environmental Virology, 2(2), 83-88. http://dx.doi. org/10.1007/s12560-010-9032-7.

Truong, B. Q., Buckow, R., Stathopoulos, C. E., \& Nguyen, M. H. (2014). Advances in High-Pressure Processing of Fish Muscles. Food Engineering Reviews, 7(2), 109-129. http://dx.doi.org/10.1007/ s12393-014-9084-9.

Wang, C.-Y., Huang, H.-W., Hsu, C.-P., Shyu, Y.-T., \& Yang, B. B. (2013). Inactivation and morphological damage of Vibrio parahaemolyticus treated with high hydrostatic pressure. Food Control, 32(2), 348-353. http://dx.doi.org/10.1016/j.foodcont.2012.12.023.

Ye, M., Huang, Y., \& Chen, H. (2012). Inactivation of Vibrio parahaemolyticus and Vibrio vulnificus in oysters by high-hydrostatic pressure and mild heat. Food Microbiology, 32(1), 179-184. http:// dx.doi.org/10.1016/j.fm.2012.05.009. PMid:22850390.

Ye, M., Huang, Y., Gurtler, J. B., Niemira, B. A., Sites, J. E., \& Chen, H. (2013). Effects of pre- or post-processing storage conditions on highhydrostatic pressure inactivation of Vibrio parahaemolyticus and V. vulnificus in oysters. International Journal of Food Microbiology, 163(2-3), 146-152. http://dx.doi.org/10.1016/j.ijfoodmicro.2013.02.019. PMid:23545264.

Ye, M., Li, X., Kingsley, D. H., Jiang, X., \& Chen, H. (2014). Inactivation of human norovirus in contaminated oysters and clams by highhydrostatic pressure. Applied and Environmental Microbiology, AEM-04260(7), 2248-2253. http://dx.doi.org/10.1128/AEM.0426013. PMid:24487534.

Yi, J., Xu, Q., Hu, X., Dong, P., Liao, X., \& Zhang, Y. (2013). Shucking of bay scallop (Argopecten irradians) using high hydrostatic pressure and its effect on microbiological and physical quality of adductor muscle. Innovative Food Science \& Emerging Technologies, 18, 57-64. http://dx.doi.org/10.1016/j.ifset.2013.02.010. 